\title{
Strategi Public Relations Kepabeanan Dan Cukai PT. Abadi Cemerlang Eratama Logistik dalam Mengedukasi Konsumen Mengenai Bahaya Impor Ilegal
}

\author{
Imanuel Hendrico, Yugih Setyanto \\ Imanuel.915150147@stu.untar.ac.id, Yugihs@fikom.untar.ac.id
}

Fakultas Ilmu Komunikasi Universitas Tarumanagara

\begin{abstract}
Customs and Excise Public Relations PT.Abadi Cemerlang Eratama Logistik (PT.ACE Logistics) is a company incorporated in Abadi Group which is tasked to be a means of information for consumers who use their services regarding applicable regulations on imports. The author is interested in this research because it wants to find out how the PT.ACE Logistics Customs and Excise Public Relations strategy in educating consumers about illegal imports. The theoretical basis used by the authors is the theory about communication, public relations, customs and excise public relations, PR strategies, and imports. The method used by the authors in this study is qualitative with a phenomenology case study approach. The author also wants to know PT.ACE Logistic Customs and Excise $P R$ strategy in educating consumers about illegal imports through interviews, observation, and library studies. So that it can be concluded, the PR and Cemerlang Eratama Logistic Customs and Excise Public Relations strategy by informing import regulations to prevent illegal imports from occurring.
\end{abstract}

Keywords: Public Relations, PR Strategy, Ilegal Imports

\begin{abstract}
Abstrak
Humas Kepabeanan dan Cukai PT.Abadi Cemerlang Eratama Logistik (PT.ACE Logistik) adalah perusahaan yang tergabung dalam Abadi Group yang bertugas menjadi sarana informasi bagi konsumen yang menggunakan jasanya mengenai peraturan yang berlaku tentang impor. Penulis tertarik dengan penelitian ini dikarenakan ingin mengetahui bagaimana Strategi PR Kepabeanan dan Cukai PT.ACE Logistik dalam mengedukasi konsumen mengenai impor ilegal. Dasar teoritik yang digunakan oleh penulis dalam penelitian ini adalah teori tentang komunikasi, hubungan masyarakat, fenomenologi, humas kepabeanan dan cukai, strategi PR, dan impor. Metode yang digunakan oleh penulis menggunakan kualitatif dan pendekatan studi kasus melalui fenomenologi. Penulis juga ingin memahami strategi PR Kepabeanan dan Cukai PT.ACE Logistik dalam mengedukasi konsumen mengenai impor ilegal melalui wawancara, observasi, dan studi kepustakaan. Sehingga dapat disimpulkan, strategi PR Kepabeanan dan Cukai PT.Abadi Cemerlang Eratama Logistik yaitu dengan cara menginformasikan peraturan impor guna mencegah terjadinya impor ilegal.
\end{abstract}

Kata Kunci: Public Relations, Strategi PR, Impor Ilegal 


\section{Pendahuluan}

Salah satu bidang pekerjaan yang selalu ada sejak zaman dahulu adalah kegiatan impor barang, yaitu kegiatan yang dilakukan dengana memenuhi kebutuhan manusia antara satu dan lainnya. Dengan tidak adanya kegiatan impor seperti ini maka kebutuhan manusia tidak akan dapat terpenuhi, karena setiap kebutuhan masing-masing individu tentu berbeda antara satu dengan yang lainnya. Perusahaan Kepabeanan adalah perusahaan yang melakukan segala sesuatu dengan pengawasan atas lalu lintas barang yang masuk maupun keluar daerah pabean serta pemungutan bea masuk dan bea keluar serta sebagai pusat informasi bagi perusahaan impor yang ingin mengimpor barang ke Indonesia (dikutip dari https:/www.academia.edu/29252678/Pengertian_Kepabeanan).

Badan Pengurus Pusat Gabungan Importir Nasional Seluruh Indonesia (BPP GINSI) Erwin Taufan, Sekretaris Jendral DPP Ginsi Periode 2017-2022 (Dikutip dari https:/www.google.com/amp/s/bisnis.tempo.co/amp/1024713/ginsi-temukan-700importir-ilegal-di-indonesia diakses pada tanggal 15 oktober 2018) menemukan 700 importir ilegal yang memasukan barang ke Indonesia. Erwin mengatakan ada 26-28 ribu importir di Indonesia. Namun, hanya 1.200 importir yang masuk menjadi anggota GINSI.

Dalam Pasal 53 Ayat (1) UU Kepabeanan dan Peraturan Menteri Keuangan Nomor 161/PMK.04/2007 mengatakan bahwa harus adanya pengawasan terhadap impor atau ekspor barang larangan dan/atau pembatasan yang intinya bahwa untuk kepentingan pengawasan terhadap pelaksanaan ketentuan larangan dan pembatasan atas impor atau ekspor wajib memberitahukan kepada Menteri Keuangan.

Perlu diketahui bahwa barang yang hendak dikirim dari luar negeri harus mempunyai surat larangan terbatas (LARTAS) di setiap jenis barang contohnya barang impor yang ingin dikirim berupa bahan mentah, maka akan memiliki lisensi yang berbeda apabila ingin mengirim barang berupa kayu atau mesin dan lain sebagainya. Hal ini yang membuat perusahaan membutuhkan waktu untuk mendapatkan izin dari larangan terbatas tersebut agar dapat mengimpor barang dari luar negeri ke Indonesia.

Dalam melakukan kegiatan impor barang tersebut, kepabeanan juga memiliki suatu daftar penggolongan barang yang dibuat secara sistematis dengan tujuan mempermudah penarifan, transaksi perdagangan, pengangkutan dan statistik yang telah diperbaiki dari sistem klasifikasi sebelumnya yang disebut Harmonized System and Coding System (HS Code). Indonesia telah mengesahkannya melalui Keppres no.35 tahun 1993 yang mengatakan bahwa tujuan dari pembuatan Harmonized System and Coding System (HS Code) bertujuan agar memberikan keseragaman dalam penggolongan daftar barang yang sistematis,demi mempermudah pengumpulan data serta analisis statistik perdagangan dunia, maupun memberikan sistem internasional yang resmi untuk memberikan kode, penjelasan, dan penggolongan barang untuk tujuan perdagangan.

Dengan demikian penulis tertarik untuk meneliti mengenai bagaimana strategi PR kepabeanan dan cukai PT.Abadi Cemerlang Eratama Logistik dalam mengedukasi konsumen mengenai bahaya impor ilegal. 


\section{Metode Penelitian}

Menurut Moleong (2005), berpendapat bahwa kualitatif adalah penelitian yang memiliki tujuan untuk memahami fenomena yang telah dialami oleh subjek penelitian seperti perilaku, persepsi, motivasi, ataupun tindakan secara holistic, maupun fenomologi melalui kata-kata, mengenai konteks secara khusus alamiah dan memanfaatkan metode ilmiah.

Hal-hal yang dapat ditemukan dalam analisis kualitatif adalah data dalam bentuk kata-kata dan bukan dengan serangkaian angka-angka. Data itu mungkin telah dibuat dan dikumpulkan melalui berbagai aneka macam cara seperti: observasi, wawancara, intisari dokumen, pita rekaman), dan biasanya "diproses" kira-kira sebelum siap untuk digunakan (melalui pencatatan, pengetikan, penyuntingan, atau alih-tulis), namun untuk analisis pada metode kualitatif tetap akan menggunakan kata-kata yang akan disusun dalam teks yang dapat diperluas (Miles dan Hubeman, 1992.

Dalam penelitian ini penulis akan menggunakan metode penelitian kualitatif dengan melakukan pendekatan studi kasus. Menurut Yin (1996:46) menyatakan studi kasus bertujuan untuk mencari pengetahuan secara empiris dan juga bertujuan untuk menyelidiki fenomena dalam konteks kehidupan nyata, bila batas-batas antara fenomena dan konteks tidak tampak secara tegas, dan dimana multisumber bukti digunakan. Studi kasus adalah langkah yang diterapkan demi mendalami suatu perseorangan lebih dalam dengan melakukan praktek secara tegas. Hal ini bertujuan agar peneliti mampu mengumpulkan dan memiliki pengertian secara lebih mendalam tentang individu yang diteliti. Studi kasus yang mampu dilakukan secara tepat di dalam kehidupan nyata dari kasus yang terjadi.

\section{Hasil Temuan dan Diskusi}

Pada bagian ini penulis akan membahas mengenai upaya humas kepabeanan dan cukai PT.Abadi Cemerlang Eratama Logistik dalam mengedukasi konsumen mengenai bahaya impor ilegal. Penulis telah melakukan perancangan sesuai hasil penelitian yang telah dan akan dijelaskan melalui langkah-langkah yang dilakukan oleh kepabeanan dan cukai untuk mengedukasi konsumen yang dimilikinya dengan menggunakan definisi Menurut Ruslan dalam Nova (2002) mengenai strategi PR, antara lain:

\section{Inform}

Strategi PR yang dapat digunakan untuk menyebarkan informasi kepada konsumen salah satunya adalah inform. Inform adalah upaya untuk memberikan informasi kepada publik guna mencapai suatu pemahaman akan hal baru, yang sudah ada, ataupun yang telah diperbaharui kepada publik maupun instansi serta pihakpihak yang terkait dengan keberadaan dan posisi humas dalam instansi itu sendiri sesuai dengan pekerjaan yang dilakukannya. 
Strategi ini dilakukan oleh Kepabeanan dan Cukai PT.Abadi Cemerlang Eratama Logistik dengan membuat sebuah website yang di dalamnya customer dapat langsung menghubungi kepabeanan untuk berkonsultasi mengenai persiapan surat, HS Code, Larangan terbatas (LARTAS) yang dibutuhkan sebelum dikirim ke pelayaran untuk mengeluarkan barang di Jakarta serta dapat mengakses jam kerja serta alamat e-mail dari humas kepabeanan tersebut. Selain itu humas kepabeanan dan cukai juga memiliki beberapa media komunikasi untuk melakukan kontak secara personal dengan konsumen pengguna jasanya seperti melalui e-mail, whatsapp, skype dan lain sebagainya.

\section{Image}

Pada dasarnya humas kepabeanan seperti humas di pemerintahan yang perannya sangat penting. Mereka diwajibkan mampu menjaga public trust dan reputasi yang baik. Salah satunya. Peran mereka memberikan informasi kepada publik terkait kinerja departemennya sendiri. Pada dasarnya kepabeanan harus menjalankan fungsinya secara cepat, tegas, dan teliti. Humas kepabeanan juga dituntut bekerjasama dan terkoordinasi dalam menjaga image perusahaan dengan keseluruhan.Pengguna jasa maupun stakeholder akan melihat perusahaan secara menyeluruh.

Menurut Muhammad Ikmal Shah selaku supervisor dokumen impor bahwa kepabeanan dan impor seperti satu kesatuan yang dimana dokumen impor akan membantu konsumen pertama kali untuk mempersiapkan dokumen-dokumen yang belum jadi sampai siap untuk diproses ketahap selanjutnya oleh kepabeanan. Karena perusahaan ini adalah perusahaan jasa, maka salah satu cara yang dapat dilakukan oleh perusahaan tersebut untuk menjaga image dari perusahaannya adalah dengan cara menyelesaikan tugas secara tepat waktu dan cepat sehingga konsumen merasa aman dan nyaman untuk memberikan tanggung jawab kepada perusahaan kepabeanan maupun dokumen impor itu sendiri, juga dengan tidak melakukan kesalahan ataupun selalu memberikan informasi kepada konsumen mengenai keberadaan barang yang mereka ingin impor masuk kedalam negara Indonesia karena terkadang barang yang diimpor tersebut mengalami masalah bisa terjadi karena satu dan lain hal seperti bencana alam yang menyebabakan barang tidak dapat di kirim untuk sementara waktu, atau ada barang yang rusak di tengah perjalanan dan lain sebagainya sehingga dengan memberikan penjelasan secara cepat kepada konsumen maka konsumen akan merasa aman dan percaya dengan kinerja dan pelayanan yang diberikan oleh perusahaan kepada konsumen itu sendiri.

\section{Lobbying and Negotiation}

Dalam dunia humas kepabeanan untuk mencapai suatu komunikasi yang baik maka kemampuan dalam melakukan lobi dan negosiasi kepada konsumen itu sangat penting. Dengan memiliki kemampuan untuk melakukan lobi dan negosiasi dengan baik maka besar kemungkinan untuk mengoptimalkan misi dari humas kepabeanan itu sendiri dalam rangka mengedukasi konsumen mengenai bahaya impor ilegal menjadi lebih mudah terlaksana. (Dikutip dari http://www.unsyiah.ac.id/FISIP/article/view/7041/3448) mengatakan bahwa komunikasi yang baik kepada konsumen akan memberikan suatu pengertian bersama, serta dengan melakukan pendekatan secara edukatif dan persuasif maka 
dapat memberikan penerangan dan saling pengertian untuk mewujudkan tujuan bersama.

Humas Kepabeanan dan Cukai PT.Abadi Cemerlang Eratama Logistik tidak hanya melakukan lobi dan negosiasi terhadap konsumen melalui sarana komunikasi yang telah ada, akan tetapi mereka terjun langsung ke lapangan, seperti mendatangi kantor impor pengguna jasa mereka dan melakukan komunikasi mengenai peraturan yang telah ada dari Kepabeanan dan Cukai maupun Pemerintah yang dapat dikonsultasikan oleh konsumen langsung kepada kepabeanan sehingga apabila suatu saat terjadi hal yang tidak diinginkan kepabeanan dan konsumen dapat bekerjasama menyelesaikan masalah tersebut, akan tetapi untuk perusahaan yang masih ingin melakukan praktik impor ilegal seperti mengangkut barang secara borongan maka kepabeanan juga dapat memberikan penjelasan kepada pelayaran apabila nanti konsumen ternyata memberikan impresi yang buruk kepada kepabeanan dan menyalahkan kepabeanan dengan alasan kepabeanan tidak memberikan informasi yang lengkap mengenai peraturan yang ada di kepabeanan maupun dalam undangundang. Maka kepabeanan dapat menjawab hal tersebut dengan memberikan beberapa bukti bahwa kepabeanan sudah benar-benar terjun ke lapangan untuk mendatangi kantor perusahaan impor dokumen untuk melakukan meeting bersama membahasa peraturan yang ada dan kepabeanan sudah berusaha untuk dapat memberikan edukasi kepada konsumen yang baru akan menggunakan jasa mereka maupun yang sudah rutin menggunakan jasa dari kepabeanan itu sendiri.

Dengan beberapa definisi-definisi yang telah disampaikan oleh Ruslan dalam Nova (2002) menjadi perwujudan dari langkah-langkah yang diambil oleh kepabeanan dan cukai PT. Abadi Cemerlang Eratama Logistik dalam praktik dilapangan untuk memberikan pelayanan kepada konsumennya.

\section{Simpulan}

Stategi yang dilakukan oleh Humas Kepabeanan dan Cukai PT.Abadi Cemerlang Eratama Logistik telah ditemukan dalam definisi yang diberikan Ruslan dalam Nova (2002) guna untuk mengedukasi konsumen mengenai bahaya impor ilegal. Strategi yang digunakan adalah Inform, Image, Lobbying and Negotiation yang diharapkan dapat menyadarkan konsumen mengenai bahaya, denda, dan hukuman yang harus ditanggung oleh perusahaan impor yang ingin berlaku curang dengan menghindari pajak lalu melakukan impor secara ilegal.

Walaupun pemerintah telah mengeluarkan peraturan terbaru yaitu NIB dan PMK158 tersebut, tentu pasti akan tetap ada perusahaan impor yang melakukan segala cara untuk menghindar dari pajak yang harus dibayar. Oleh karena itu Humas Kepabeanan dan Cukai PT.Abadi Cemerlang Eratama Logistik akan terus berusaha untuk memberikan edukasi khususnya untuk konsumen baru yang menggunakan jasa mereka maupun perusahaan impor yang sudah menggunakan jasa dari perusahaan kepabeanan tersebut. 


\section{Ucapan Terima Kasih}

Penulis mengucapkan terima kasih untuk narasumber yang sudah meluangkan waktu sebagai narasumber informasi bagi penulis guna menyelesaikan penelitian dan data-data yang diperlukan sehingga penelitian dapat diselesaikan

\section{Daftar Pustaka}

Andi Susilo. 2008. Pintar Ekspor Impor, Jakarta: TransMedia Pustaka.

Cutlip, Scott; Allen H Center dan Glen M. Broom, 2007. Effective Public Relations, Jakarta: Kencana Prenada Media Group.

Husein Umar. 2008. Metode Penelitian Skripsi dan Tesis Bisnis, Penerbit: PT.Raja Grafindo Persada, Jakarta.

Lexy J.Moleong. 2005. Metodologi Penelitian Kualitatif, Jakarta: Rosda.

Mahmud Machfoeddz. 2004. Komunikasi Bisnis Modern, Yogyakarta, BPFE.

Moleong, Lexy J. 2011. Metode Penelitian Kualitatif: Edisi Revisi (Cetakan keduapuluh sembilan), Bandung: PT.Remaja Rosdakarya.

Marolop Tandjung. 2011. Prosedur Ekspor Impor, Jakarta: Salemba Empat.

Nazir, Moh. 2003. Metode Penelitian (Cetakan Kelima). Jakarta: Ghalia.

Nova, Firsan. 2011. Crisis Public Relations: Strategi PR Menghadapi Krisis. Jakarta:PT.Rajagrafindo Persada.

Nurjaman dan Khaerul Umam. (2012). Komunikasi dan Public Relations, Jakarta: Pustaka Setia.

Rakhmat, Jalaluddin. (2012). Metode Penelitian Komunikasi. Bandung: PT.Remaja Rosdakarya.

Rachmat Kriyantono. (2012). Public Relations Writting, Jakarta: Kencana Prenada Media.

Ruslan Rosady, (2007). Kiat dan Strategi Kampanye Public Relations. Penerbit PT.RajaGrafindo: Jakarta.

Uchjana Effendy, Onong, (2006). Hubungan Masyarakat. Penerbit PT Remaja Rosdakarya: Bandung.

Online

Astuti, S., Putri, I., \& Ali, D. (2017). Strategi Komunikasi Program Internet Sehat Dan Aman Kementerian Komunikasi Dan Informatika Republik Indonesia (Studi Kasus Evaluasi Program Incakap Tahun 2015.Jurnal Komunikasi, 8(1), 25-35. doi:http://dx.doi.org/10.24912/jk.v8i1.47

Evita, Yugih Setyanto. (2018). Strategi Marketing Public Relations Dalam Meningkatkan Jumlah Pelanggan Di Pt.Bach Multi Global. Jurnal Prologia, 2(2), 312-319. doi: http://dx.doi.org/10.24912/pr.v2i2.3596

Della Resita, Ahmad Junaidi. (2018). Analisis Strategi Pemberitaan Media Alternatif Untuk Isu-Isu Berkaitan Dengan Kekerasan Pada Perempuan (Studi Kasus 
Imanuel Hendrico, Yugih Setyanto: Strategi Public Relations Kepabeanan Dan Cukai PT. Abadi Cemerlang Eratama Logistik dalam Mengedukasi Konsumen Mengenai Bahaya Impor Ilegal

Magdalene Sebagai Media Online). Jurnal Koneksi, 2(2), 269-276. doi: http://dx.doi.org/10.24912/kn.v2i2.3895

https://www.academia.edu/29252678/Pengertian_Kepabeanan

www.kemenperin.go.id

https://scholar.google.co.id/citations?user=1mc1b0UAAAAJ\&hl=id

http://ww.jim.unsyiah.ac.id/FISIP/article/view/7041/3448 